\title{
The co-localization of stanniocalcin protein, mRNA and kidney cell markers in the rat kidney
}

\author{
C K C Wong, M A Ho and G F Wagner
}

Department of Physiology, Faculty of Dentistry and Medicine, The University of Western Ontario, London, Ontario, Canada N6A 5C1

(Requests for offprints should be addressed to G F Wagner)

\begin{abstract}
Stanniocalcin (STC) is a glycoprotein hormone that was first discovered in fish and recently identified in mammals. STC immunoreactive (STCir) cells have been identified in rat kidney and there is also evidence that the hormone functions as a regulator of renal phosphate homeostasis. In the present study we have identified STCir cells and tubules in the rat kidney by correlative immunocytochemistry using antibodies to STC and specific antigenic markers (Tamm-Horsfall protein and anion exchanger-1). The cellular sites of STC gene expression were also identified by in situ hybridization. Correlative immunocytochemistry revealed that STCir was present in all
\end{abstract}

proximal straight tubule cells, all cortical thick ascending limb cells, all distal convoluted tubule cells, and both principal and $\alpha$-intercalated cells of the collecting duct system. On the other hand, in situ hybridization revealed that the STC gene was expressed only in cortical and medullary collecting duct cells. This suggests either that STC is being sequestered by segments that do not express the gene (making them putative targets of the hormone), or that STC mRNA levels were simply too low in these other segments to be detected by in situ hybridization.

Journal of Endocrinology (1998) 158, 183-189

\section{Introduction}

Stanniocalcin (STC) is a glycoprotein hormone that was first characterized in bony fish (Wagner et al. 1986) where it is produced by unique endocrine glands known as the corpuscles of Stannius (CS) (Stannius 1839). CS are derived from the pronephric/mesonephric ducts (Garrett 1942, Wendelaar Bonga \& Pang 1986, Kaneko et al. 1992) and are located on the surface of the kidneys in most fish species. Elevated plasma calcium levels stimulate the secretion of STC, which is released into the circulation to inhibit gill and intestinal calcium transport (So \& Fenwick 1977, 1979, Wagner et al. 1986, 1988, 1993, Sundell et al. 1992) and the renal excretion of inorganic phosphate (Pi) in order to restore normocalcemia (Lu et al. 1994).

There are no CS glands or comparable structures in mammals. However, the existence of STC in mammals has been proven by the recent characterization of full-length cDNAs encoding human and mouse STC (Chang et al. 1995, 1996, Olsen et al. 1996). Functional studies with recombinant human STC (hSTC) have demonstrated that STC is capable of inhibiting renal phosphate excretion in the rat through a mechanism that involves increasing the activity of the proximal tubule $\mathrm{Na} / \mathrm{Pi}$ cotransporter (Olsen et al. 1996, Wagner et al. 1997). Therefore STC participates in the renal regulation of Pi homeostasis in both fishes and mammals. However, unlike fishes where STC gene expression is confined to CS tissue, the mammalian STC gene is widely expressed in tissues as diverse as ovary, heart, and kidney, suggesting that the mammalian hormone may function instead as a paracrine mediator.

In a previous study we mapped and characterized the distribution of STC immunoreactive (STCir) cells in rat kidney. The protein was abundant in all cells making up the cortical thick ascending limbs and distal convoluted tubules, and in most cells making up the collecting duct system. However, cell types and tubule segments were identified solely on the basis of morphology, location and tinctorial staining characteristics (Haddad et al. 1996), leaving some doubts as to their true identity. Furthermore, the mere presence of STC protein did not prove that the cells in question actually synthesized the hormone. Hence the issue as to where the STC gene was expressed in kidney was also left unresolved. In the present study we have addressed both of these questions, first by colocalizing STC with cell and segment-specific markers (Tamm-Horsfall protein and anion exchanger-1) and second by identifying the sites of STC gene expression by in situ hybridization.

\section{Materials and Methods}

Tissue preparation

Male Wistar rats $(300 \mathrm{~g})$ were anaesthetized with a $100 \mathrm{mg} / \mathrm{kg}$ i.p. injection of Inactin (Research Biochemicals International, Natick, MA, USA). The kidneys were 
fixed by an intracardiac infusion of $4 \%$ paraformaldehyde in $0.15 \mathrm{M} \mathrm{NaCl}$, buffered to $\mathrm{pH} 7 \cdot 4$ with $0.01 \mathrm{M}$ sodium phosphate. Tissues were dehydrated and embedded in paraffin and $4 \mu \mathrm{m}$ tissue sections were mounted on microscope slides. Prior to immunocytochemistry or in situ hybridization, the slides were heated for $1 \mathrm{~h}$ at $50{ }^{\circ} \mathrm{C}$, deparaffinized in xylene and rehydrated.

\section{Immunocytochemistry}

Antibodies to Tamm-Horsfall protein which are specific for cortical thick ascending limb and distal convoluted tubules (Lopez et al. 1993), and antibodies to anion exchanger-1 (Brown et al. 1996) which are specific for collecting duct $\alpha$-intercalated cells were kindly supplied by Drs J R Hoyer and S Alper respectively. The antiserum employed for STC immunocytochemistry was generated in rabbits against recombinant $\mathrm{hSTC}$ and has already been characterized for specificity by immunocytochemistry (Haddad et al. 1996, Olsen et al. 1996). The staining procedure involved pretreatment of tissue sections with $10 \%$ normal goat serum in diluent buffer $(10 \mathrm{mM}$ Tris $\mathrm{pH}$ $7 \cdot 5$ containing $150 \mathrm{mM} \mathrm{NaCl}$ ) to reduce non-specific staining, followed by an overnight incubation at $4{ }^{\circ} \mathrm{C}$ with antiserum (hSTC: 1:100 dilution; Tamm-Horsfall protein: 1:200; anion exchanger-1: 1:500) and a $1 \mathrm{~h}$ incubation at $22{ }^{\circ} \mathrm{C}$ with goat anti-rabbit IgG coupled to horseradish peroxidase $(1: 200)$. The slides were washed three times for $15 \mathrm{~min}$ in the diluent buffer, after each antiserum application. The sites of peroxidase activity were visualized in $0.03 \%$ 3,3-diaminobenzidine, containing $0.01 \%$ hydrogen peroxide. Control procedures included the application of preimmune rabbit serum in lieu of STC antiserum. The immunostained slides were counterstained with hematoxylin and mounted under coverslips. Some slides were also stained with either FITC-coupled second antibodies or a Glucose Oxidase ABC kit according to the manufacturer's instructions (Vector Labs, Burlington, Ontario, Canada).

\section{In situ hybridization}

A 815 bp cDNA encoding 248 amino acids of mouse STC was generated by PCR of total RNA derived from mouse ovary. The primers were designed on the basis of the published cDNA sequence of mouse STC (Chang et al. 1996), the forward primer (25 mer) corresponding to bp 228-252 (5'-ATGCTCCAAAACTCAGCAGTGA TTC- $\left.3^{\prime}\right)$ and the reverse primer $(18 \mathrm{mer})$ to bp 10261043 (5'-ACACTCAAAGTTGGTGTG-3') of the known mouse sequence (Chang et al. 1996). The PCR product was purified, subcloned into pBSKII and subjected to dideoxy sequencing for verification that mouse STC had indeed been amplified and cloned. When employed as a probe in Northern blot analysis of total RNA derived from mouse and rat kidney the cDNA hybridized specifically to a $4 \mathrm{~kb}$ message (results not shown), precisely as described by Chang et al. (1996). For riboprobe synthesis, the plasmid was linearized with restriction enzymes for the synthesis of sense and anti-sense cRNAs to a specific activity of $2-4 \times 10^{8}$ d.p.m. $/ \mu \mathrm{g}$ RNA with $\left[{ }^{35} \mathrm{~S}\right]$ UTP according to the manufacturer's instructions (Pharmacia, Baie d'Urfe, Quebec, Canada). Probe size in all cases was estimated to be full length by electrophoresis in $6 \%$ polyacrylamide gels.

In situ hybridization was performed as described by Sterba et al. (1993) for the localization of STC mRNA in fish STC cells. Hydrated tissue sections were treated with $0 \cdot 2 \mathrm{M} \mathrm{HCl}$ for $30 \mathrm{~min}$ at room temperature, followed by a water wash for $30 \mathrm{~min}$ at $65^{\circ} \mathrm{C}$ and proteinase $\mathrm{K}$ treatment at $37{ }^{\circ} \mathrm{C}$ for $30 \mathrm{~min}(1 \mu \mathrm{g} / \mathrm{ml}$ proteinase $\mathrm{K}$ in $0 \cdot 1 \mathrm{M}$ Tris- $\mathrm{HCl}, \mathrm{pH} 8 \cdot 0$, containing $50 \mathrm{mM}$ EDTA). Tissues sections were prehybridized for $2 \mathrm{~h}$ at $50{ }^{\circ} \mathrm{C}$ in $50 \%$ formamide, $0.2 \mathrm{M}$ sodium chloride, $20 \mathrm{mM}$ Tris$\mathrm{HCl} \mathrm{pH} 8 \cdot 0,1 \mathrm{mM}$ EDTA, $10 \times$ Denhardt's solution, and $50 \mu \mathrm{g} / \mathrm{ml}$ denatured salmon sperm DNA.

Hybridization reactions were carried out under siliconized glass coverslips in prehybridization solution containing $10 \%$ dextran sulfate, $500 \mu \mathrm{g} / \mathrm{ml}$ yeast tRNA, $20 \mathrm{mM}$ DTT and $0 \cdot 1 \mathrm{ng} / \mu$ l labeled cRNA probe. The coverslipped slides were immersed in mineral oil and incubated at $50{ }^{\circ} \mathrm{C}$ for $18 \mathrm{~h}$.

After hybridization, the slides were rinsed in three baths of chloroform to remove residual mineral oil. Slides were then washed twice for $1 \mathrm{~h}$ at $22^{\circ} \mathrm{C}$ in $4 \times \mathrm{SSC}, 10 \mathrm{~min}$ in $0.3 \mathrm{M}$ ammonium acetate and for $30 \mathrm{~min}$ at $65^{\circ} \mathrm{C}$ in posthybridization buffer $(50 \%$ formamide, $0.3 \mathrm{M} \mathrm{NaCl}$, $20 \mathrm{mM}$ Tris- $\mathrm{HCl} \mathrm{pH} 8 \cdot 0,1 \mathrm{mM}$ EDTA and $0 \cdot 1 \mathrm{M}$ DTT), followed by a room temperature wash in $2 \times$ SSC. Single stranded/non-specifically bound riboprobe was digested in $20 \mu \mathrm{g} / \mathrm{ml}$ RNase A and $10 \mathrm{U} / \mathrm{ml}$ RNase T1 for $30 \mathrm{~min}$ at $37^{\circ} \mathrm{C}$, followed by washing in $2 \times$ SSC for 15 min four times at $22{ }^{\circ} \mathrm{C}$ and $0.1 \times \mathrm{SSC}$ at $65^{\circ} \mathrm{C}$ for $30 \mathrm{~min}$. The slides were dehydrated in graded ethanols containing $0.3 \mathrm{M}$ ammonium acetate and dipped in Amersham LM-1 emulsion (diluted 1:1 with $0.3 \mathrm{M}$ ammonium acetate). Emulsion-coated slides were stored at $4{ }^{\circ} \mathrm{C}$ in light-tight boxes containing silica gel as desiccant. Slides were developed (Kodak D-19) and counterstained with hematoxylin.

\section{Results}

As we have already described the appearance and morphology of STCir cells and tubules in a previous study (Haddad et al. 1996) we have confined our histological observations here to the co-localization of STC with antigenic markers. Essentially, the present results confirmed our earlier observations in the rat. As shown in Fig. 1, STCir proved to be closely correlated with both antigenic markers such that STC protein was present in all 

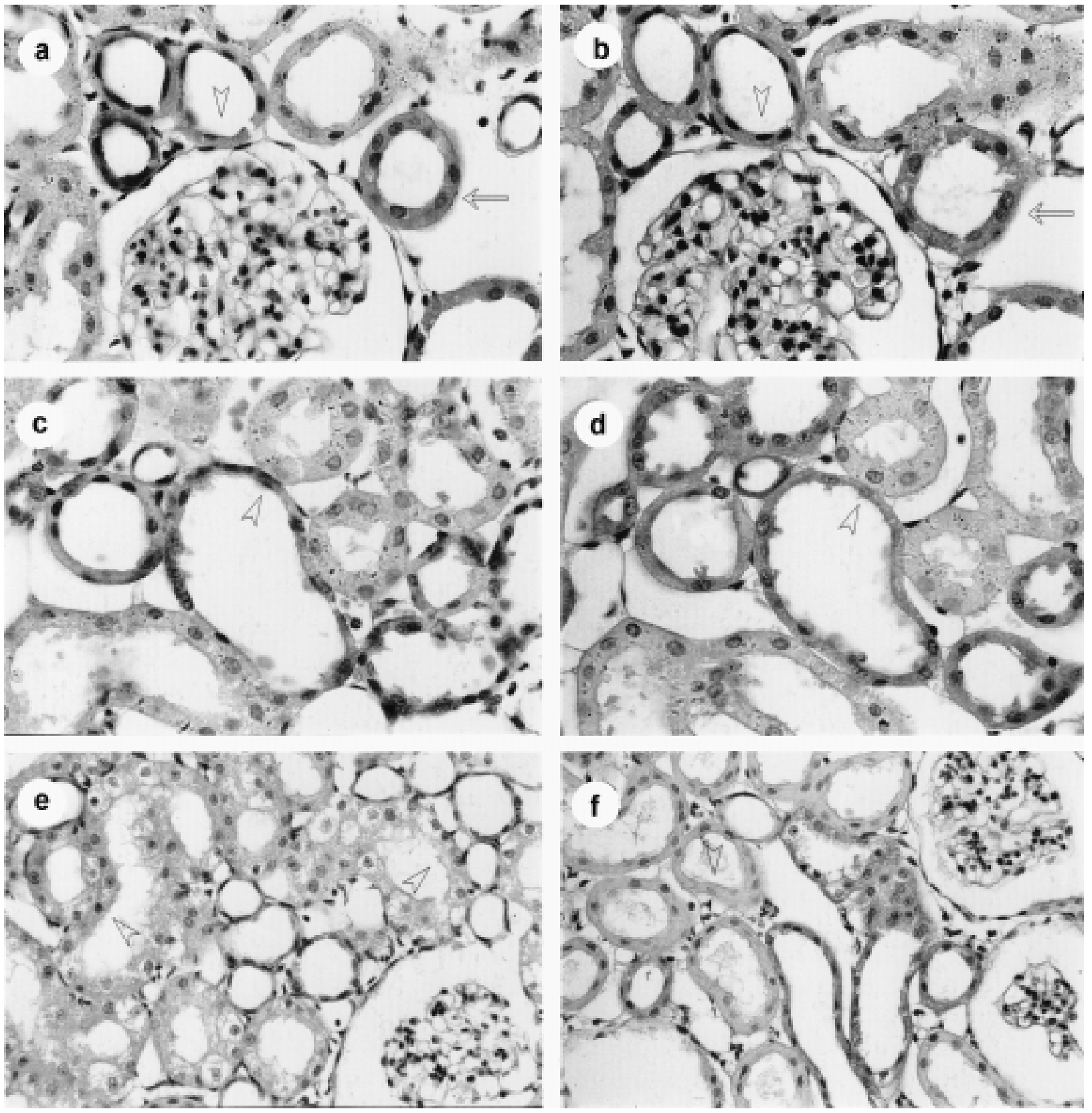

Figure 1 Correlative immunocytochemical localization of STC and antigenic markers in rat kidney. (a) Tamm-Horsfall protein and (b) STC co-localization in cortical thick ascending limb (arrowhead) and distal convoluted tubule (arrow). (c) Anion exchanger-1 and (d) STC co-localization in collecting duct $\alpha$-intercalated cells (arrowhead). (e and f) STC staining proximal tubule is specific for the straight segment. Note the specific staining in proximal straight tubule (e, arrowheads) and complete absence of staining in proximal convoluted tubules (f, arrowhead).

cells of cortical thick ascending limb, all cells of the distal convoluted tubules, and both the principal and $\alpha$-intercalated cells of cortical and medullary collecting duct. Figure $1 \mathrm{a}$ is a cross-section through the kidney cortex showing several STCir nephron segments which were identified as being cortical thick ascending limb and distal convoluted tubules based on the fact that they also contained high levels of Tamm-Horsfall Protein (Fig. 1b). In the case of cortical and medullary collecting duct, we also obtained a definitive and clearcut co-localization of STC with anion exchanger-1 in $\alpha$-intercalated cells (Fig. 1c and d). Furthermore, because the majority of 

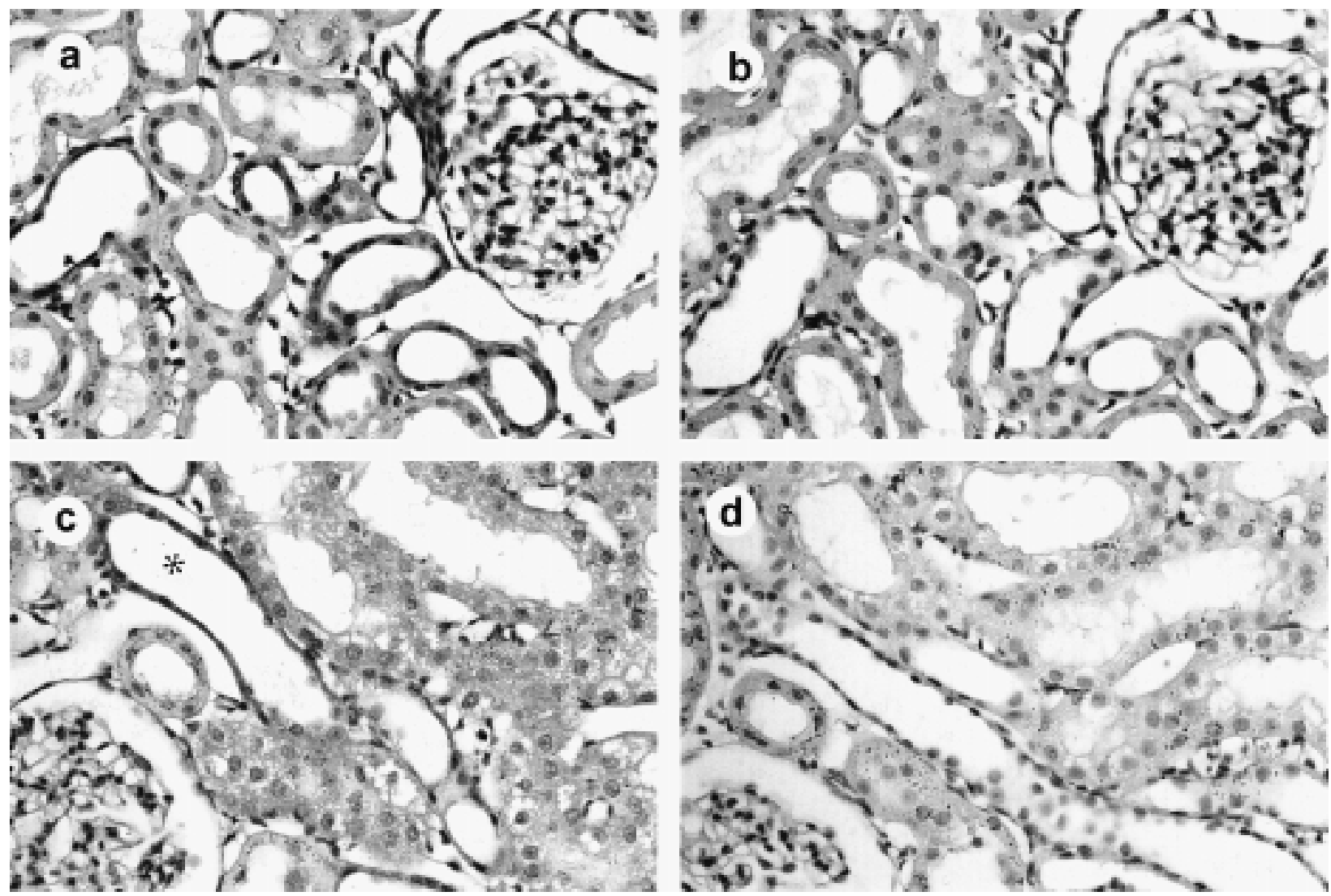

Figure 2 Immunocytochemical staining controls. (a) Specific staining for STC in the distal convoluted tubules in outer cortical kidney. (b) The adjacent section treated with antiserum preabsorbed with STC and in which tubule staining has been abolished. (c) Specific staining for STC in proximal straight tubules and cortical collecting duct (asterisk). (d) Adjacent section treated with antiserum preabsorbed with STC in which staining has been abolished.

collecting duct cells contained STCir (not just the $\alpha$-intercalated cells), this suggested that STC was in fact present in both the principal and the $\alpha$-intercalated cells. All of the macula densa cells were STC positive as well (not shown on figures), whereas glomeruli were always devoid of hormone.

We also identified STCir in an additional locus, proximal straight tubule, which was not observed in previous studies. Figure 1e illustrates the strong staining for STC in proximal straight tubules, but its complete absence in proximal convoluted tubules from the same animal (Fig. 1f). All tubular staining for STC proved to be specific as staining was abolished when the antiserum was preabsorb with purified hormone (Fig. 2a-d).

When in situ hybridization was applied to rat kidney, the distribution of STC mRNA differed considerably from the distribution of protein, and some typical examples of message distribution are showed in Fig. 3. The use of anti-sense cRNA probes yielded a high density of silver grains over medullary (Fig. 3a and b) and cortical collecting ducts (Fig. 3d and e). The density of grains observed over the same tubules after staining with sense probes was low in comparison, and similar to background levels over other regions of the kidney (Fig. 3c). Therefore, the staining observed over collecting duct cells was specific to anti-sense probes. Figure $3 \mathrm{f}$ shows a higher magnification of cortical collecting ducts showing silver grains concentrated over the cell cytoplasm. It can also be seen here that the number of grains over glomeruli, proximal tubules, cortical thick ascending limb and distal convoluted tubules are low and similar to background levels over non-tissue areas. The conclusion upon analysis of numerous rat kidneys was that STC gene expression, as determined by in situ hybridization, was confined to collecting duct cells.

\section{Discussion}

STC is a newly described regulator of phosphate homeostasis in mammals (Olsen et al. 1996) that reduces renal phosphate excretion though a mechanism that involves increasing the activity of the proximal tubule 

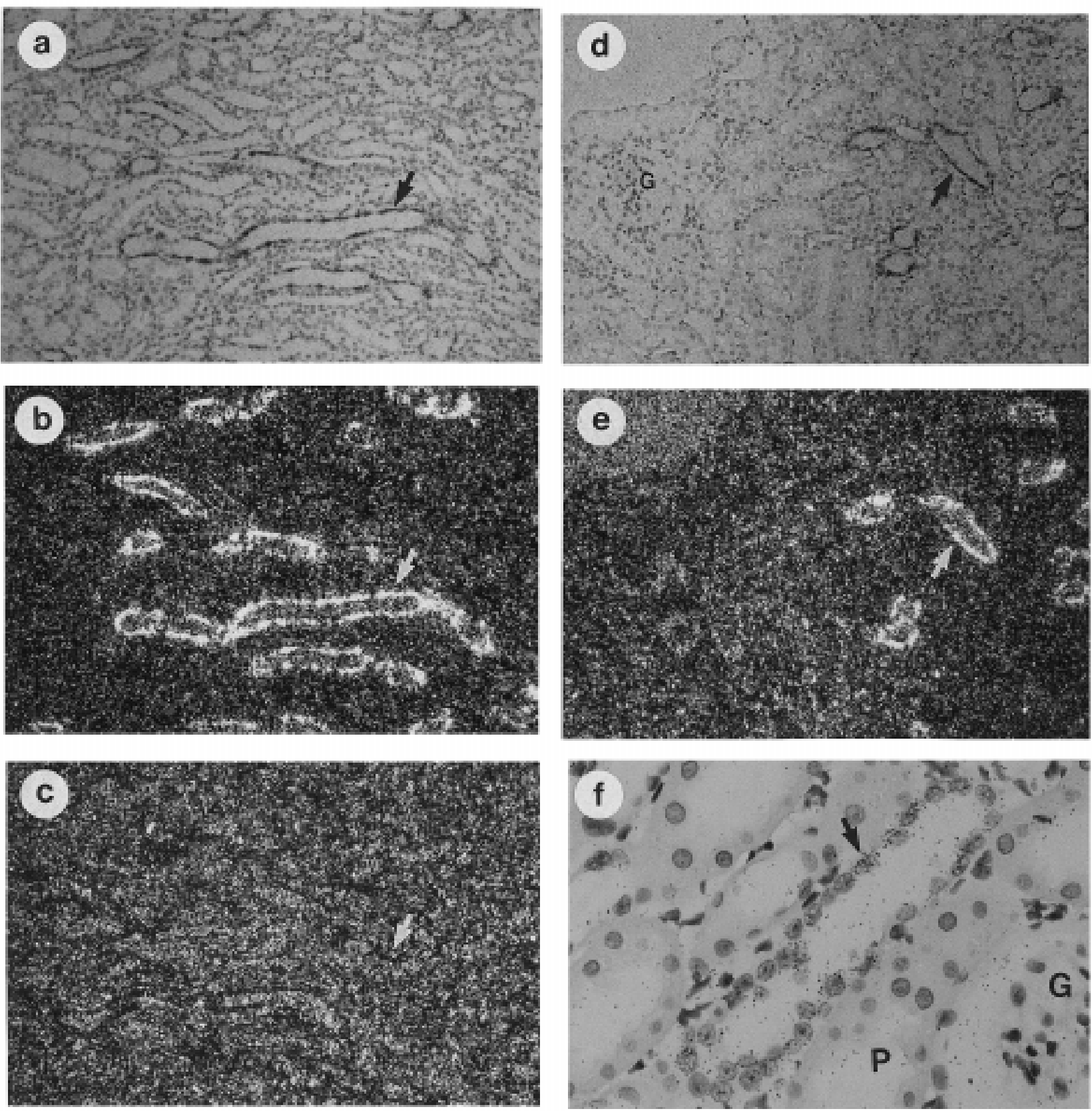

Figure 3 STC gene expression in rat kidney. (a) Bright and (b) dark field images of the same area in outer medullary kidney following in situ hybridization with antisense probe $(160 \times)$ ). Silver grains are concentrated over the collecting ducts (arrow). (c) Tissue section adjacent to that in (b) shows that no specific staining is obtained with sense probe (arrow). (d) Bright and (e) dark field images of cortical kidney following in situ hybridization with antisense probe $(160 \times)$. Silver grains are again concentrated over the collecting ducts (arrow). (f) Silver grains (arrow) concentrated over individual cortical collecting duct cells $(630 \times)$. P, proximal tubule; G, glomerulus.

$\mathrm{Na} / \mathrm{Pi}$ cotransporter (Wagner et al. 1997). However, the source of the hormone exerting this effect has remained open to question as the gene is expressed in many different tissues. One possible source is kidney itself as the gene is abundantly expressed in kidney tissue (Chang et al. 1995,
1996, Olsen et al. 1996). However, precisely where it is expressed and whether or not renally derived STC is involved in regulating renal function are questions that have not been addressed. Previous work in the rat has shown that the hormone is abundant in several nephron 
segments (Haddad et al. 1996), but that study did not address precisely where the gene was expressed. Therefore in this report we have co-localized STC protein with antigenic markers for specific cell types and nephron segments (Tamm-Horsfall protein and anion exchanger-1 protein) and identified the sites of STC gene expression by in situ hybridization. As a result, we can now confirm that all cortical thick ascending limb and distal convoluted tubule cells contain STC protein, as do collecting duct principal cells and collecting duct $\alpha$-intercalated cells. Some cells in the collecting duct were not stained, however, by antibodies to STC or the antigenic markers used, and were therefore categorized as presumptive $\beta$-intercalated cells simply by the process of elimination. In addition, in contrast to earlier findings the present study revealed substantial amounts of STCir in most of the cells making up the proximal straight tubules.

The distribution of STC mRNA was not at all consistent with that of STCir. We found that the gene was exclusively expressed in collecting duct cells and saw no evidence of transcripts in proximal straight tubules, thick ascending limbs or distal convoluted tubules, all of which contained abundant levels of STCir. One possible explanation for this discrepancy is that message levels were simply too low in these tissues to be detected by in situ hybridization. This occurs in fish STC cells, for instance, where the level of gene activity is often too low to be seen by in situ hybridization (Sterba et al. 1993, Wagner 1994). Hence, other nephron segments may in fact express the gene, but at very low levels. Alternatively, the STC transcript may be unusually unstable in other segments of the nephron. We also cannot rule out the possibility that these segments do not express the gene under any circumstances, and that STC is being sequestered here. This is not a common phenomenon, but it would not be unprecedented as the sequestering of secreted proteins has been reported in the case of both corticosteroid binding globulin and basic fibroblast growth factor (Scrocchi et al. 1993, Blottner et al. 1997). If STC were being sequestered, then the source of the protein would presumably be the collecting duct cells juxtaposed to the sites of its accumulation. This would implicate renally derived STC as a local regulator of kidney function, operating by way of paracrine and/or short-loop endocrine pathways. In this regard, the accumulation of STC in proximal straight tubules may be a consequence of its actions on tubular phosphate transport (Olsen et al. 1996, Wagner et al. 1997). That having been said, we also cannot rule out the possibility of STC being sequestered by the kidneys following its release into the blood elsewhere.

With the benefit of hindsight, the expression of the STC gene in collecting duct cells makes sense from an evolutionary perspective. Embryologically, the collecting duct system develops from the dividing ureteric bud which is an outgrowth of the mesonephric duct. The proximal tubules, loops of Henle, maculae densae and distal convoluted tubules have a different origin, however, being derived instead from the metanephrogenic blastema (Ekblom 1992, Clapp \& Abrahamson 1994). Because fish STC cells also arise from the pronephric/mesonephric duct (Garrett 1942, Wendelaar Bonga \& Pang 1986, Kaneko et al. 1992), this implies that the STC cells in fish and those in mammalian kidney share a common embryological origin, the only difference being that the mammalian cells remain at their site of ontogeny instead of coalescing into discrete glands. It is interesting to note that the CS glands in the most primitive bony fishes also remain closely associated with the nephrons like those in mammalian kidney (Youson \& Butler 1976), but it remains to be seen if these differences in anatomy translate into differences in function.

In summary, our results indicate that the STC gene is exclusively expressed in the collecting duct system of the rat kidney. On the other hand, STC protein was present in most of the cells making up the proximal straight tubule, cortical thick ascending limb, macula densa and distal convoluted tubule, as well as the collecting duct system. Hence, the collecting duct appears to be the site of STC production and secretion, leaving the other nephron segments as putative targets of the hormone. If this interpretation is correct then STC may be acting in a paracrine or short-loop endocrine fashion to regulate ion transport by the proximal tubules and other nephron segments.

\section{Acknowledgements}

This study was supported by scholarship and operating grant support from the Medical Research Council of Canada $(\mathrm{G} \mathrm{F} \mathrm{W)}$ ) and the Croucher Foundation of Hong Kong (C K C W). We also thank Drs J R Hoyer and S Alper for supplying us with antisera. We are also grateful to Dr G E DiMattia and Mr Robin Varghese for their assistance in preparing the mouse STC cDNA.

\section{References}

Blottner D, Stapf C, Meisinger C \& Grothe C 1997 Localization, differential expression and retrograde axonal transport suggest a physiological role of FGF-2 in spinal autonomic neurons of the rat. European Journal of Neuroscience 9 368-377.

Brown D, Stuart-Tilley A, Lydon J, Tyszkowski R, McLaughlin M \& Alper S 1996 Antigen retrieval in cryostat tissue sections and cultured cells by treatment with sodium dodecyl sulfate (SDS). Histochemistry and Cell Biology 105 261-267.

Chang AC-M, Janosi J, Hulsbeek M, De Jong D, Jeffrey KL, Noble JR \& Reddel RR 1995 A novel human cDNA highly homologous to the fish hormone stanniocalcin. Molecular and Cellular Endocrinology 112 241-247.

Chang AC-M, Dunham MA, Jeffrey KJ \& Reddel RR 1996 Molecular cloning and characterization of mouse stanniocalcin cDNA. Molecular and Cellular Endocrinology 124 185-187. 
Clapp WL \& Abrahamson DR 1994 Development and gross anatomy of the kidney. In Renal Pathology with Clinical and Functional Correlations, edn 2, pp 3-59. Eds CC Tisher \& BM Brenner. Philadelphia: Lippincott.

Ekblom P 1992 Renal development. In The Kidney: Physiology and Pathophysiology, edn 2, pp 475-501. Eds DW Seldin \& G Giebisch. New York: Raven Press.

Garrett FD 1942 The development and phylogeny of the corpuscles of Stannius in ganoid and teleostean fishes. Journal of Morphology 70 41-67.

Haddad M, Roder S, Olsen HS \& Wagner GF 1996 Immunocytochemical localization of stanniocalcin cells in the rat kidney. Endocrinology 137 2113-2117.

Kaneko T, Hasegawa S \& Hirano T 1992 Embryonic origin and development of the corpuscles of Stannius in chum salmon (Oncorhynchus keta). Cell and Tissue Research 268 65-70.

Lopez CA, Waterhouse P, Hoyer JR, Denhardt DT \& Wilson PD 1993 Heterogeneity of osteopontin expression among nephrons in mouse kidneys and enhanced expression in sclerotic glomeruli. Laboratory Investigation 69 355-363.

Lu M, Wagner GF \& Renfro JL 1994 Stanniocalcin stimulates phosphate reabsorption by flounder renal proximal tubule in primary culture. American Journal of Physiology 267 R1356-R1362.

Olsen HS, Cepeda MA, Zhang QQ, Rosen CA, Vozzolo BL \& Wagner GF 1996 Human stanniocalcin: a possible hormonal regulator of mineral metabolism. Proceedings of the National Academy of Sciences of the USA 93 1792-1796.

Scrocchi LA, Orava M, Smith CL, Han VKM \& Hammond GL 1993 Spatial and temporal distribution of corticosteroid-binding globulin and its messenger ribonucleic acid in embryonic and fetal mice. Endocrinology 132 903-909.

So YP \& Fenwick JC 1977 Relationship between net ${ }^{45}$ calcium influx across a perfused isolated eel gill and the development of poststanniectomy hypercalcemia. Journal of Experimental Zoology 200 259-264.

So YP \& Fenwick JC 1979 In vivo and in vitro effects of Stannius corpuscles extract on the branchial uptake of ${ }^{45} \mathrm{Ca}$ in stanniectomized North American eels (Anguilla rostrata). General and Comparative Endocrinology 37 143-149.

Stannius H 1839 Ueber nebenniere bei knochenfischen. Archives of Anatomical Physiology 6 97-101.
Sterba T, Wagner GF, Schroedter IC \& Friesen HG 1993 In situ detection and distribution of stanniocalcin mRNA in the corpuscles of Stannius of sockeye salmon, Oncorhynchus nerka. Molecular and Cellular Endocrinology 90 179-185.

Sundell K, Bjornsson B Th \& Kawauchi H 1992 Chum salmon (Oncorhynchus keta) stanniocalcin inhibits in vitro intestinal calcium uptake in Atlantic cod (Gadus morhua). Journal of Comparative Physiology B 162 489-495.

Wagner GF 1994 The molecular biology of the corpuscles of Stannius and regulation of stanniocalcin gene expression. In Fish Physiology, vol XIII, ch 9, pp 273-306. Eds N Sherwood \& C Hew. New York: Academic Press.

Wagner GF, Hampong M, Park CM \& Copp DH 1986 Purification, characterization and bioassay of teleocalcin, a glycoprotein from salmon corpuscles of Stannius. General and Comparative Endocrinology 63 481-491.

Wagner GF, Fenwick JC, Park CM, Milliken C, Copp DH \& Friesen HG 1988 Comparative biochemistry and physiology of teleocalcin from sockeye and coho salmon. General and Comparative Endocrinology 72 237-246.

Wagner GF, Fargher RC, Milliken C, McKeown BA \& Copp DH 1993 The gill calcium transport cycle in rainbow trout is correlated with plasma levels of bioactive, not immunoreactive, stanniocalcin. Molecular and Cellular Endocrinology 93 185-191.

Wagner GF, Vozzolo BL, Jaworski E, Haddad M, Kline RL, Olsen HS, Rosen CA, Davidson MB \& Renfro JL 1997 Human stanniocalcin inhibits renal phosphate excretion in the rat. Journal of Bone and Mineral Research 12 165-171.

Wendelaar Bonga SE \& Pang PKT 1986 Stannius corpuscles. In Vertebrate Endocrinology: Fundamentals and Biochemical Implications, vol I Morphological Considerations, pp 439-464. Eds PKT Pang \& MP Schreibman. San Diego: Academic Press.

Youson JH \& Butler DG 1976 Fine structure of the adrenocortical homolog and the corpuscles of Stannius of Amia calva L. Acta Zoologica 57 217-238.

Received 15 October 1997

Revised manuscript received 16 January 1998 Accepted 4 March 1998 